\title{
Human Resource Planning and Use of Technology to Company Efficiency and Employment Creation. Case Study: PT. Go-Jek Indonesia
}

\author{
Muhammad Calvin Capnary \\ Postgraduate Program of Science in Management \\ Universitas Indonesia \\ Depok, Indonesia \\ calvincapnary@gmail.com
}

\begin{abstract}
Times certainly followed by the development of technology. The economic and business sectors too, did not escape the influence of technology. In a business, the role of technology was already entered in the various sectors, including human resource. The role of technology is used not only to meet the needs of fast-paced in the organization, but also to achieve the objectives of the organization in terms of efficiency. This process is the role of human resources planning in the organization. This study is an attempt to determine the relationship between the use of technology by the human resource planning in the organization for the purpose of efficiency in the organization and creation of new jobs. A qualitative approach was considered the most appropriate approach to the study objectives. Researchers used a qualitative approach to the design of case studies with the respondents with a position as a human resource planner in the PT. Go-Jek Indonesia. The study found that the use of technology has an impact on the efficiency and the creation of new employment in the e-commerce companies in Indonesia (PT. GoJek Indonesia).
\end{abstract}

Keywords: Human Resource Planning, Technology, Efficiency, Employment Creation

\section{INTRODUCTION}

Labor is one of the most important element in the organization. It can be said that the good or bad of an organization depends on the quality of the people who work or are in the organization. However, the presence of these workers will not mean anything if the organization is not able to use it properly. An organization must have a strategy related to how to make the most of the workers in the organization. It is considered very important in order to support the creation of sustainable strategic success which is the goal of the organization for the survival of the company or organization.

One of the main problems in managing the workforce is the cost that is issued by the organization. Sum of money with very large number and facilities issued by organization as compensation and benefits. The huge costs are considered commensurate with the contribution to be granted. In addition, many organizations assume that if they lose a good worker organization will spend more on labor costs to get a replacement. Costs incurred will be much greater for the recruitment, training, and development of the candidate's ability to improve the performance of the organization. Therefore, it takes the role of human resources planning. Human resource planning is useful to define talent management related processes, systems, and components based support of the goals of an organization [1]. In general, human resources planning has the function to define the purpose of the organization, create a strategy to achieve these goals, and develop plans and comprehensive strategies to integrate and coordinate the activities of the organization [2]. Human resources planning also have a responsibility in making rules and useful programs to provide benefits to the performance of an organization [3] which also has a link with efficiency in an organization. The amount of costs to be incurred by the organization and also a high risk of losing talent that makes some companies racked his brain as a solution to these problems. Organization must maximize limited resources among unlimited needs such as capital construction, technology upgrades, and expansion of facilities [4]. In order to survive with limited capital, then organization prosecuted for being able to dynamically creative in order to survive in the midst of intense competition [5][6][7]. One solution to these problems is to increase the efficiency of the organization by replacing the role talent to technology. The technology has a role to assist in the efficiency of human resources [8]. Such as making systems, store systems, manipulation, analysis, and distribute obtain information related to human resources, personal activities, as well as the characteristics of the organization. It is confirmed that the technology sector have a role in human resources and processes within the organization. The use of this technology is called the "Automation" [9]. Automation has several objectives, such as (1) improving productivity, (2) reduce or eliminate the routine work is manual, (3) improve safety for workers, (4) improve product quality of service, (5) reducing production time, (6 ) do work that cannot be done manually, (7) avoid the high costs, and (8) anticipate a labor shortage. Automation is starting to be done in some companies. For example, The New York Times media have already started using the technology in the fields of their wedding announcement. At the wedding column, readers can freely enter all sorts of relevant information which would then be packed by a system that has been created. Another example is Tawabo, a robot owned by Tokyo Tower, one of the tourist destinations in Japan. Tawabo replace the role of a customer 
service to provide any information to assist the tourists during a visit to Tokyo Tower. The retail sector was not immune from the phenomenon of transfer of human resources with technology. It is related to changing the format of a physical business into the digital or technology. In the UK for example, the state of the Queen Elizabeth showed that the number of employees in the retail sector fell from 3.2 million employees in 2008, to 3 million people by 2014 [10]. It is believed to be the result of a 40,000s psychal store are turning to online. And the process of buying and selling through online media above can be referred to e-commerce. E-commerce has the definition of the process of buying and selling a product electronically by consumers or from company to company with a computer as an intermediary in the transaction of business [11]. E-commerce is a combination of technologies, applications, and business processes dynamically connecting businesses, consumers, and communities through electronic transactions and electronic exchanges of goods, services, or information [12]. E-commerce is not only happening in the retail business sector, but also in the transportation business sector. Today, many developing ecommerce which is engaged in the transportation sector. Started by Uber, a four-wheeled transportation businesses that use the application for their booking process. In Indonesia, ecommerce businesses in the transport sector is started by GoJek, Grab bike, as well as other companies engaged in the same field.

On the other hand, the use of technology not only has the role of the company's efficiency in reducing the number of workers who have an impact on the cost burden to the administration of salaries, but also have contributed to the employment creation. Data shows that the technology has a role in the creation of 6.2 million new jobs in small and medium-sized businesses [13]. As an example we can see from the cases of Uber, bike Grab and Go-Jek. The use of technology-based application that is able to create new job opportunities in the transportation sector in Indonesia. The application-based transport business is able to create new job opportunities through their business models in the form of a "partnership" or can be called by crowdsourcing. There are three components in crowdsourcing [14]. They are (1) the organization, (2) people / society itself, and (3) programs that connect between the two. The program in the form of information sharing and technology brought together by internet [15] [16] as a business model for the solution of problems faced by the company [17]. Partnership system itself means that the partners are not part of the organization or can be said to come from outside the organization with an attachment in the form of partnership.

Based on the discussion above, this study investigates the role of human resource planning in the process of technology utilization to efficiency in the company and the employment creation. Using a sample of which is an e-commerce company engaged in the transportation sector in Indonesia, namely PT. Go-Jek Indonesia. This study aims to identify the role of human resource planning sector of the efficiency, utilization of technology, and the effect of the use of these technologies on the efficiency in human resources sector and employment creation in the e-commerce company engaged in the transportation sector in Indonesia.

\section{LITERATURE REVIEW}

\section{A. Human Resource Planning}

Human resource planning is a process to identify, define and plan the human resource needs of the organization in the short term and long term. Human resource planning is a process for determining the need for human resources within the organization to identify and plan all kinds of things related to human resources to meet the demand for human resources [18]. Human resource planning is useful for determining how much and what kind of people that is needed to support an organization [19]. Human resource planning divided into two kinds [19], namely (1) hard human resource planning and (2) soft human resource planning. Human resource planning has the responsibility to determine how many employees are needed in the organization and behavior, motivation and commitment of these employees. Whereas soft human resource has responsible to establish a culture based on the organization objectives. argues that human resource planning process must be in accordance with business needs based on the problems and changes in circumstances that have an effect on the policies and actions of the organization. The purpose of human resource planning into five objectives [19]:

1) Attract and retain workers with the knowledge, skills, and competencies appropriate

2) Anticipating the problems of shortage or surplus of workers

3) Developing through good training and flexible work force to contribute to the organization's ability to uncertainties and changes in environment

4) Reduce dependence on external recruitment process to develop a repository as a development strategy

5) Improve the utilization of labor by introducing more flexible working system.

Human resource planning also has a relationship with the determination of strategies that will be done by the organization, including the determination of the use of technology in the human resources sector. Human resource planning in a strategy aimed at getting the raw materials in the form of work style with quality, expertise, knowledge, and the potential to be developed through training in the future [21]. This includes how many people are needed in the short and long term, the type of skills needed in the future, a way to discover the needs of the existing resources, where to find them, things that are needed to develop basic capabilities, identify employees with potential and capabilities, attract and retain key employees, expanding opportunities to maximize placement of employees by increasing flexible working, and that harm reduction organization. Human resource planning has a function to form a long-term strategy in organizations that include recruitment to training, development and career management, to resignation [22]. Human resource planning also has a relationship with the strategy and objectives of the organization. 


\section{B. Human Resource Planning to Technology and Efficiency}

One strategy that is conducted by the human resource planning is the use of technology. The use of technology to replace the role of a man or automation was first introduced and used by Henry Ford in 1908 in the company of his automobile manufacturers i.e. Ford. There are some characteristics of automation, that are without operator assistance mechanism, a transfer tool, machining operations are performed sequentially, objects moving by themselves, high utilization, and in the form of special purpose the establishment of the engine block [23]. This automation using technology such as pneumatic, electrical, and computerize. The core of the automation itself is to replace the role of humans in organizations using the machine. The use of this technology is called the "Automation" [9]. Automation has several objectives, namely (1) improving productivity, (2) reduce or eliminate the routine work is manual, (3) improve safety for workers, (4) improve product quality of service, (5) reducing production time, (6) do work that cannot be done manually, (7) avoid the high costs, and (8) anticipate a labor shortage.

The fundamental changes in the business environment which causes a shift in the practice of human resources for the realization of a sustainable competitive advantage [24]. This has resulted in the need for unskilled labor declined and many clerical jobs were taken over by automatic machines and technologies. Changes in the business environment makes the resource sector become a critical asset, therefore the company should do the calculations in the development and management of human resources. One is with the use of technology. The rapid development of technology in support of a businesses growth to survive in the competition as a strategic role in ensuring the performance demanded as a function within the organization. Examine the role of technology in the form of an electronic human resource management of the human resources sector. Human resources are the most valuable resource in an organization [25]. Therefore, the use of electronic technology in the form of human resource management can help companies in the efficiency and strategically in achieving the goals set by the company. Electronic management resources help to facilitate the functions of human resources to create and open up new opportunities to achieve organizational success. Electronic human resource management functions as meeting the needs of the organization in the form of a knowledge-based economy. It is useful to maximize the potential and productivity of employees that must be owned by a company to survive in the market competition. Human resources is a vital sector in the organization and management together with the interplay of technology and co-exist in the functions and processes of the organization [26]. Researchers used the methodology of collecting data from multiple sources such as journals, books, and some of the articles obtained from the website or the internet. In this study, researchers get the fact that the technology to assist and encourage human resource management to achieve effectiveness and efficiency in the organization. However, use of this technology should be accompanied by the implementation of human resources traditionally incorporate the expertise, knowledge, and capabilities of the HR professionals in applying their knowledge through technology.

\section{Technology to Employment Creation}

Not only have a role in the efficiency of the organization, the technology also has a role in opening up new jobs. Technology not only eliminate jobs available, but also able to create new jobs [27]. Researcher shows data taken from Bureu of Labor Statistics in 2005, there has been an increase in employment by $55 \%$. Data shown in the fact that the technology has a role in the creation of 6.2 million new jobs in the small and medium business industries with a revenue growth of $\$ 770$ Billion in five countries with the largest economy in the world [13]. Deloitte said that the growth of technology also has impact on the creation of new jobs [28]. Researchers say that the technology is not only able to reduce the number of cost in production and employees, but also able to create new job opportunities. Information technology has the role of the organization in optimizing the efficiency, productivity, and compliance with networks in business processes [29]. Researchers reveal that in the 20th century, many organizations seek to minimize the direct role of the human in all lines on their business chain. It is not only having an impact on the efficiency, but also open up new jobs. Researchers showed that in the US alone, the use of technology responsible for the creation of 800,000 new jobs in the manufacturing sector.

Based on literature review above, the researchers tried to prove the role of human resource planning and utilization of technology to the efficiency made by organizations that have an impact on the employment creation. This study focuses on a case study in PT. Go-Jek Indonesia as the sample of research respondents.

\section{RESEARCH MODEL}

Based on the above discussion, the study sought to investigate the role of human resource planning to the decision to use the technology with the goal of efficiency in ecommerce company engaged in the field of transport, namely PT. Go-Jek Indonesia that affect the creation of new jobs within the organization.

This study aims to answer some of the questions that will be submitted. That is:

1) Do the human resource planning has a role in determining the use of technology in PT. Go-Jek Indonesia?

2) What factors were the reason for human resource planning in the use of these technologies?

3) What role are replaced by technology in the organization of PT. Go-Jek Indonesia?

4) What is the role of technology in helping the efficiency in the sector of human resources within the organization PT. Go-Jek Indonesia?

5) Is there any influence of efficiency caused by technology to the creation of new jobs? 


\section{PROFILE RESPONDENT}

This study uses PT. Go-Jek Indonesia as the focus of research. PT. Go-Jek Indonesia or better known as "Go-Jek" ecommerce company that is engaged in the transportation of two-wheeled vehicles such as motorcycles or can be called the "Go-Ride". Use application that can be downloaded by means of using a smartphone. Go-jack not only offer services such as taxis, but also a delivery service of food or can be called the "Go-Food", massage services call or called "Go-Massage", services to clean the house or room cleaning service calls called "Go-Clean", services of beauty treatments or called as "Go-Glam", delivery services or "Go-Send", services to grocery shopping day or "Go-Mart", services to provide information about the existence of Transjakarta buses or "Go Busway", and also transport services in the form of a fourwheel truck to deliver goods or can be called as a" Go-Box ". PT. Go-Jek Indonesia uses a system of partnership with the riders in the area. On Sumatra, the services of Go-Jek can already be found in Palembang and Medan. On Java island can be found in Jakarta, Bogor, Depok, Tangerang, Bekasi, Semarang, Bandung, Surabaya, and also the latest in DI Yogyakarta. Go-Jek also able to find in other areas such as Bali, Balikpapan and Makassar. This partnership system means that the driver has the authority and its own decision to take or not an existing order, but the PT. Go-Jek Indonesia still provide a minimal amount of orders that need to be secured by the motorcycle taxi driver. Has the tagline "An Ojeks for Every Need", Go-jack made with vision and purpose to alleviate and reduce unemployment in Indonesia.

PT. Go-Jek Indonesia selected as respondents by the researchers with the consideration that PT. Go-Jek Indonesia is one of the innovators and originators of e-commerce in the sector of transportation services in Indonesia. In addition, PT. Go-Jek Indonesia also indicated to have a business strategy by using the technology in their business.

\section{RESEARCH METHOD}

PT. Go-Jek Indonesia selected as respondents by the researchers with the consideration that PT. Go-Jek Indonesia is one of the innovators and originators of e-commerce in the field of transport services in Indonesia. In addition, PT. Go-Jek Indonesia also indicated to have a business strategy by using the use of technology in their business.

This study used a qualitative research by conducting interviews with the relevant sections. Using snowball sampling technique, this technique is done by taking one key respondent. furthermore find other respondents by asking to the key respondents before [30]. The interview was conducted by Mr. Agung Setiawan as Vice President of Human Resources PT. Go-Jek Indonesia. Mr. Agung Setiawan elected directly by the company after researchers communicated the research themes to the company. Mr.agung chosen because it is considered the most understand to the themes that researchers take. After that, Mr. Agung choose Mr. Seto Lareno as an informan respondent. Implementation of this research was conducted after researchers and respondents agree with the time and place of the interview. Type of this research is descriptive analysis, which describes what the result of collecting data and information on the case became the focus of the study which will then do the analysis in such a way as to answer the purpose of research

The process of data analysis is done by examining the entire data in the can and provide code (coding) on each keyword. Reduction is done by creating an abstraction, which is a summary of the various things that are considered crucial, process, and statements that are considered important. Next is the preparation of the units which are then categorized into groups based on common topics. Researchers are also conducting the preparation into a summary to facilitate the interpretation and compilation of the dynamics of each case. Having examined its validity, the researchers then entered the stage of interpretation.

\section{RESULT AND DISCUSSION}

\section{A. Human Resource Planning and Use of Technology}

Researchers conducted the interview with Mr. Agung Setiawan as Vice President of Human Resources PT. Go-Jek Indonesia. In the interview obtained information that PT. GoJek Indonesia already using the technology in their organization. PT. Go-Jek Indonesia in the recruitment process have a collaboration with a website called Linkedin. Cooperation with the Linkedin is a decisions taken by the human resources department of PT. Go-Jek Indonesia. But besides using Linkedin website, based on interviews conducted with Mr. Seto Lareno obtained the fact that PT. GoJek Indonesia in the recruitment process is also working with the website called Kalibrr apart from Linkedin. In addition to recruiting process, PT. Go-Jek Indonesia is also using technology-based application that can be downloaded via Google PlayStore and Apple Store in their operational processes, especially in the booking process. Use of the application began in 2015, aims to reduce the function of the call center in PT. Go-Jek Indonesia. However, the decision to use the technology in the application form is not a decision of human resource planning in PT. Go-Jek Indonesia. According to Mr. Agung, the use of technology in the form of the application is a decision made by the CEO of PT. Go-Jek Indonesia, namely Mr. Nadiem Makarim. This is in line with the information obtained from Mr. Seto. He said that the use of the application is the decision taken by the Mr. Nadiem Makarin and Mrs. Alamanda Shantika Santoso as Vice President of Product Technology at PT. Go-Jek Indonesia.

Keywords of the use of technology in the recruitment process in PT. Go-Jek Indonesia:

"In the recruitment process, we work closely with the Linkedin website .." (Agung Setiawan)

"In addition to LinkedIn, We cooperate with the website from Philippines that is called Kalibrr. But still use Linkedin to see the profile of candidates.. "(Seto Lareno) 
Keywords of the role of CEO Mr. Nadiem Makarim and team in the use of applications in the PT. Go-Jek Indonesia:

"It used to booking through customer services. But in 2015 we started to using Go-Jek application .. "(Agung Setiawan)

"... The decision by Mr. Nadiem Makarim and team .." (Agung Setiawan)

"Beside of Mr.Nadiem, who was decisions in the application usage is Mrs. Alamanda, Vice President of Technology .." (Seto Lareno)

\section{B. Technology to PT. Go-Jek Indonesia Effciency}

The use of technology has an influence on the efficiency of the company, including PT. Go-Jek Indonesia. According to Mr. Agung, use Linkedin website that has a huge impact on cost efficiency and time that is issued in the recruitment process PT. Go-Jek Indonesia. Efficiency will be undertaken in the form of cost reduction and to attend job fairs or similar events for the recruitment process. The exciting discovery was the focus of efficiency that is done by human resources planning section PT. Go-Jek Indonesia not through the use of technology, but with the election strategy based of the region to get talent. In 2015, PT. Go-Jek Indonesia chose Yogyakarta Special Region as an area to build their talent development centers, especially in the IT sector named Go-Jek Tech Valley. Special Region of Yogyakarta was chosen because, according to Mr. Agung area is rife young and creative talents. Besides filled with young creative talents, charges issued in the form of salaries and benefits was fairly cheap associated with the Provincial Minimum Wage (UMP) is low. This is in line with the results of the interview with $\mathrm{Mr}$. Seto who said that Yogyakarta is filled with a very creative talent exceeds other cities in Indonesia. The use of technology in the application form will be undertaken by PT. Go-Jek Indonesia also have an impact on the time efficiency of riders and other partner. With the use of the application, partners rider can more easily and quickly to get consumers. In contrast to conventional 'ojek' should going around to get the consumer which means it takes time and a greater cost. In the interview, the researcher also get an exciting new findings. According to Mr. Agung, with the use of these technologies not only have an impact on efficiency, but also have an impact on consumer satisfaction of PT. Go-Jek Indonesia

Keyword of Efficiency in the recruitment process:

".. it is men we do not need to spend money to join a job fair or other similar events .." (Agung Setiawan)

Keyword of Efficiency through the use of the application:

"With the application, we do not have a rider goes around to get consumers again .." (Agung Setiawan)
"... Our riders can get consumers from their home, while watching, they can get consumers and should not be around like a general ojek.." (Seto Lareno)

Keywords of efficiency through selection based on region:

"... The focus of our efficiency even in the Yogyakarta region selection, because there consists of creative people. Besides its low cost .. "(Agung Setiawan)

"Yogyakarta is full of creative people, more than other cities in Indonesia .." (Seto Lareno)

Keyword of the use of technology to customer satisfaction:

"Technologies for consumer satisfaction. Efficiency and customer satisfaction should be in line .. "(Agung Setiawan)

"Prospective employees easier if you would like to apply to us. our employees are also customers of us.. "(Agung Setiawan)

\section{Efficiency and Use of Technology to Employment Creation} in PT. Go-Jek Indonesia.

According to the information through interviews with $\mathrm{Mr}$. Agung, the efficiency and the use of technology in PT. Go-Jek Indonesia also have an influence in the employment creation at PT. Go-Jek Indonesia. According to him, customer satisfaction plays an important role. The efficiency and the use of technology has a major influence on consumer satisfaction PT. Go-Jek Indonesia. This can be evidenced by the increasing consumer demand for services is on offer regional coverage of PT. Go-Jek Indonesia. With the increase of services on offer and coverage by PT. Go-Jek Indonesia, PT. Go-Jek Indonesia need to add more workers in the company. Currently, PT. GoJek Indonesia have expanded their business in 15 regions across Indonesia. From the number of employees of PT. GoJek Indonesia was increasing very quickly. Recorded increase in number of employees amounted to 1400 employees with details of the total employees of 200 people in January 2015 to 1,600 in December 2015 and still continues to grow. In addition, riders partner of PT. Go-Jek Indonesia was increased to 200,000 people from 15,000 . It is confirmed that the efficiency and the use of technology will be undertaken by PT. Go-Jek Indonesia have an impact and influence on the employment creation.

Keywords of efficiency with the use of technology to the creation of new jobs:

"From the beginning of January 2015 our employees rose from 200 to 1600 people in December 2015 .." (Agung Setiawan)

"At the beginning, our driver are 15,000 people, and now there are about 200,000 people .." (Agung Setiawan) 


\section{CONCLUSION}

One of the strategies undertaken by the planning department of human resources is to replace the role of humans with technology. Changes over the function of the human or manually by the technology or can be called by automation has a role within the organization to achieve efficiencies. By using the technology, organizations can not only minimize the outlay in terms of compensation and other facilities to the members of the organization by reducing the role of humans manually within the organization, but also to maximize the performance as a competitive advantage within the organization in order to meet customer satisfaction. Customer satisfaction plays an important role in the development of the organization. Consumer satisfaction can attract new customers who use the services of the organization means to create new jobs within the organization. With increasing the market also means increased revenue and profits of the organization

\section{REFERENCES}

[1] Smith, N.Q. A Strategic Approach to Role-Based Talent Management. Training, July/August. 2011.10-12.

[2] Robbins, S. P., Judge, T. A. . Organizational behavior (14th ed.). Upper Saddle River, NJ: Prentice Hall. 2011

[3] Koch, M.J. and McGrath, R. Improving Labor Productivity: Human Resource Management Policies Do Matter. Strategic Management Journal, Vol 17 No, 5, pp. 1996. 335-54

[4] Ogden, J. Health Psychology: a textbook. 5th edition. Open University Press, McGraw-Hill. 2010.

[5] Himam, F. Inventing the Future. Koln, Germany: Lambert Academic Publishing, 2009.

[6] Cappelli, P. Talent Management for the Twenty-First Century Talent Management for the Twenty-First Century. Harvard Business Review, 2008 .

[7] Garrow, V., Hirsh, W. Talent Management: Issues of Focus and Fit. Public Personnel Management, 37(4), 2008, 389-402.

[8] Prosvirkina. E. Importance of Information Technology in Reaching HR Effectiveness: Example of Local and International Banks in Russia. Humanity \& Social Sciences Journal 8 (1): 35-40. Moscow, Russia: National Reserach University, 2013.

[9] Kalpakjian, S. Manufacturing Engineering and Technology (First Edition). Addison-Wesley Pub. Company, 1989.

[10] New Research Highlight Potential for Technology to Help Fuel Significant Revenue and Job Growth by SMEs; New BCG Research Finds That if More SMEs Adopted the Latest IT Tools, They Could Boost Their Combined Revenues by $\$ 770$ Billion and Create More Than 6 Million Jobs in Just Five Country. New York: PR Newswire, 2013.

[11] Zhao, Yuziang, and Qinghua Zhu. "Evaluation on Crowdsourcing Research: Current Status and Future Direction, 2012.
[12] Baum. D. E-Commerce. New Jersey: Oracle corp, 1999.

[13] Dickinson, H. Retail 2020: Fewer But Better Jobs. British Retail Consortium Report, 2016.

[14] Zhao, Yuziang, and Qinghua Zhu. Evaluation on Crowdsourcing Research: Current Status and Future Direction, 2012

[15] Aitamurto, Tanja, Aija Leiponen, and Richard Tee,. The Promise of Idea Crowdsourcing - Benefits, Contexts, Limitations." Nokia Ideasproject White Paper, 2011.

[16] Howe, Jeff. The Rise of Crowdsourcing.Wired Magazine, 2006.

[17] Brabham, Daren. Crowdsourcing as a Model for ProblemSolving. Convergence 14: 2008; 75-90

[18] Bulla,D.N., Scott, P.M. Manpower requirements forecasting: a case example, in (eds) D Ward, T P Bechet and R Tripp, Human Resource Forecasting and Modelling. The Human Resource Planning Society, 1994.

[19] Prashanti. K. Human Resource Planning - An Analytical Study. International Journal of Business and Management Invention: 2319 8028. India: JNTUH, 2013.

[20] Casson. S. Revaluating company Man power planning in the light of some practical experiences. Institute of Manpower Studies, Brighton. 1978

[21] Keep.E. Corporate training strategies in J Storey, New Perspectives on HRM. United Kingdom: Oxford, 1989

[22] Nankervis, A.R., Compton,R.L.,\& McCarthy,T.E. Strategic Human Resource Management (2nd Edition). Australia: Nelson Publishing, 1996.

[23] Zarbo, R.J., \& D'Angelo. R. Tranforming to a Quality Culture: The Henry Ford Production System. Detroit: American Journal of Clinical Pathology, 2006.

[24] Ellitan, L. Praktik-Praktik Pengelolaan Sumber Daya Manusia dan Keunggulan Kompetitif Berkelanjutan. Jurnal Manajemen dan Kewirausahaan Vol. 4, No. 2, 2002: 65-76

[25] Li.M and Ye.M. The Role of Electronic Human Resource Management in Contemporary Human Resource Management. Open Journal of Social Sciences 3, 2015: 71-78

[26] Banerji.S.C. A Study of Issues \& Challanges of Implementation of Information Technology in HRM. Global Journal of Management and Business Studies. Vol. 3, No. 4. 2013: Pp. 435-440.

[27] Rigdon. J.E. Technology (A Special Report: On The Job-Give and Take: Technology has the Power to Create Lots of New Jobs, it Can Also Eliminate Them. U.S.A: Wall Street Journal,Eastern Edition, 1994

[28] Cole. A, De.D., Stewart. I. Technology and People: The Great JobCreating Machine. United Kingdom: Delloite LLP, 2015.

[29] Norbusch. K.D dan Bernaden. J.A. The Multiplier Effect: There Are More Manufacturing Related Jobs Than You Think; The Embrace of Smart Manufacturing Technique Will Turn Conventional Wisdom About Indirect Jobs Creation on Its Head and Change the Image of the Industry Itself. Manufacturing Executive Leadership Journal. Rockwell Automation, 2012

[30] Brown, K.M. Reconciling moral and legal collective entitlement: Implications for community-based land reform. Land Use Policy 2 , 2006:4 